\title{
Primary Culture of Lepidopteran Adherent and Suspension Cells from Larval Testes of Bombyx mori
}

\author{
Bombyx mori'nin Larval Testislerinden Elde Edilen Yüzeye \\ Bağımlı ve Süspanse Lepidopter Hücrelerinin Primer Kültürü
}

\author{
Research Article
}

Hüseyin Can*, Seçkin Soya, Mehmet Salih Yıkılmaz

Faculty of Science, Department of Biology, Ege University, Bornova, Izmir, Turkey.

\section{A B S TR AC T}

\begin{abstract}
$\mathrm{n}$ this study, first aim is to establish primary insect cell culture from larval testes of Bombyx mori. The other aim is to investigate the appropriate cells for establishing continuous cell lines. Testes obtained from $5^{\text {th }}$ instar larvae of B. mori were cultured in Grace's insect medium. Consequently, it was seen that primary cell culture from testes of $B$. mori resulted in suspension and adherent cell lines. In addition, this study showed that while adherent cells were not appropriate choice to initiate continuous cell line, suspension cells were suitable to establish continuous cell lines from Bombyx mori testes.
\end{abstract}

\section{Key Words}

Insect cell culture, larval testes, Bombyx mori, primary cell culture.

\section{öz}

\begin{abstract}
alışmada öncelikli olarak Bombyx mori'nin larval testislerinden primer böcek hücre kültürü oluşturulması $\zeta$ amaçlanmıştır. Diğer bir yandan yetiştirilen bu hücrelerin sürdürülebilir hücre hatları oluşturma potansiyelleri araştırılmıştır. Testisler Bombyx mori'nin 5.evre larvalarından elde edilmiş ve Grace insect medium'da kültüre edilmiştir. Sonuç olarak, Bombyx mori 5.evre larva testislerinden elde edilmiş primer böcek hücre kültüründe hücrelerin süspanse ve yüzeye bağımlı olmak üzere iki şekilde bulunduğu gözlenmiştir. Ek olarak, bu çalışmada Bombyx mori testislerinden sürdürülebilir hücre hatları oluşturmak için yapışkan hücrelerin değil, süspanse hücrelerin daha uygun oldukları tespit edilmiştir.
\end{abstract}

\section{Anahtar Kelimeler}

Böcek hücre kültürü, larval testis, Bombyx mori, primer hücre kültürü.

Article History: Received: Sep 5, 2016; Revised: Oct 22, 2016; Accepted: Jan 5, 2017; Available Online: Apr 1, 2017

DOI: 10.15671/HJBC.2017.154

Correspondence to: H. Can, Faculty of Science, Department of Biology, Ege University, Bornova, Izmir, Turkey. 


\section{INTRODUCTION}

nsect cell culture is a very useful tool for biology, genetics and medicine [1], since it is frequently used for cell-virus interaction studies [2-5], virus propagation [6-7], development of new pesticides $[1,8]$ and the illumination of signal transduction pathways [9]. Also, insect cell culture is preferred for production of recombinant humanized proteins because, similar to mammalians, insects have post translational modifications in protein expressions $[10,11]$.

Although more than 500 insect cell lines have been established, it is stated that new studies are necessary to find more effective insect cell lines for production of recombinant proteins [12].

Among the invertebrates, insect cell cultures are frequently established from Lepidoptera and Diptera, and various tissues belonging to these insects such as reproductive tissues (ovaries/ testes), hemolymph, imaginal discs, fat bodies, midguts, nervous, endocrine and muscular systems or whole embryo and neonate larvae have been cultured [13].

It is suggested that each cell sources used for culture have some advantages and disadvantages. Briefly, although embryos and neonate larvae are commonly used to establish continuous cell lines since they have more undifferentiated cells, these cell sources are not suitable for culture of specific tissue. Obtaining of hemocytes from hemolymph for culture is relatively easy but these cells are hard to be grown. Imaginal disc is a very good tissue for culture due to having undifferentiated cells but current problem for this tissue is that it is tiny and hard to find or dissect because of its transparent structures. Although fat cells are an abundant cell types, these may have some problems associated with cell division. Midgut, which is an important tissue for insect, may not be a good choice for culture because of the potential for contamination. Although nervous, endocrine and muscular systems are important tissues like midgut, there are rare or no cultures associated with these tissues because of their limited potential in growth. Among the reproductive tissues, ovaries have been frequently used as a cell source to establish continuous cell lines and also successful results from reproductive tissues have been obtained [12].

Another example of reproductive tissue is testis and it has been cultured for many years. Initial study was started by culturing the testes of Samia cecropia [14]. Since then, testes obtained from different species of insects have been cultured in several studies [15-24]. Even if different species of insects have been used in these studies, most of these studies have common properties such as; (1) development of spermatogenesis have been studied, (2) continuous cell lines haven't been investigated and (3) cultures have been established for a short time.

As different from other studies generally focusing on spermatogenesis, the first aim in this study is to establish primary insect cell culture from testes of Bombyx mori using Grace's insect medium. The other aim is to investigate the appropriate cells obtained from testes for establishing continuous cell lines.

\section{MATERIALS AND METHODS}

\section{Silkworm (Bombyx mori)}

The silkworm eggs were obtained from Bursa Kozabirlik Company, Bursa, Turkey. After hatching, larvae were reared until $5^{\text {th }}$ instar larvae in laboratory at $25 \pm 1{ }^{\circ} \mathrm{C}$ and $75 \pm 5 \%$ relative humidity with fresh mulberry leaves [7].

\section{Dissection of Larvae}

The $5^{\text {th }}$ instar larvae were sterilized by submerging in $70 \%$ ethyl alcohol for $3 \mathrm{~min}$ and dissected under a stereoscopic binocular microscope (Carl Zeiss). Testes located in abdomen were removed from larvae, washed three times with sterilized water and transferred to cell dissociation solution (non-enzymatic, Sigma). Finally, they were cut into small pieces with a microscalpel. Nearly 15-20 larvae were used for each petri dish [21].

\section{Primary Culture}

Primary cell cultures were prepared from testes using some modifications [7,21]. Removed testes were transferred to petri dishes (Becton Dickinson, 35×10 mm) for cultivation with $500 \mu \mathrm{l}$ Grace's insect medium (pH: 6.7, Sigma-Aldrich) 
containing 10\% FBS (fetal bovine serum, SigmaAldrich), pen/strep (100 units/ml, AppliChem), gentamycin $(50 \mathrm{mg} / \mathrm{ml}$, Sigma-Aldrich). After the $1^{\text {st }}$ day of cultivation, $1 \mathrm{ml}$ of Grace's insect medium was added to each petri dish. Cells were incubated at $26^{\circ} \mathrm{C}$ in an incubator (Binder, CB 53) by replenishing $500 \mu$ of culture medium for each week. Each petri dish was routinely examined with an inverted microscope (Olympus, CK 40) and cell diameters were measured using Olympus LC Micro software from the cells in three different areas.

\section{Subculture of Adherent and Suspension Cells} When adherent cells had covered $80 \%$ of petri dish, they were removed by trypsin $(0.25 \%$, Sigma-Aldrich) treatment. Supernatant was discarded after removed cells were centrifuged at $500 \mathrm{~g}$ for $10 \mathrm{~min}$, and Grace's insect medium with 10\% FBS was added to the pellet for trypsin inhibition. Finally, cells were subcultured to new petri dishes containing $500 \mu \mathrm{l}$ of medium with split ratio of 1:2.
For suspension cells, supernatant was discarded after they were centrifuged at $500 \mathrm{~g}$ for $10 \mathrm{~min}$, and suspension cells were subcultured to new petri dishes containing $500 \mu \mathrm{l}$ of medium with split ratio of 1:2.

\section{RESULTS}

\section{Primary Culture}

In $5^{\text {th }}$ day of culture, there were cells in suspension and bottom of petri dish. Nearly all of them were spherical cells which were approximately $10 \mu \mathrm{m}$ in diameter. Giant cells which were bigger than 20 $\mu \mathrm{m}$ in diameter were also available and these cells had a distinctive nucleus (Figure $1 \mathrm{~A}$ ). In $14^{\text {th }}$ day of culture, suspension cells significantly increased and these cells were subcultured to the new petri dishes with split ratio of 1:2 (Figure $1 \mathrm{~B}$ ). In $20^{\text {th }}$ day of culture, there was an increase in number of cells situated in both bottom of petri dish in which they were called as adherent cells. Adherent cells which had different sizes started to seem as tightly linked to those of neighboring (Figure 1C).
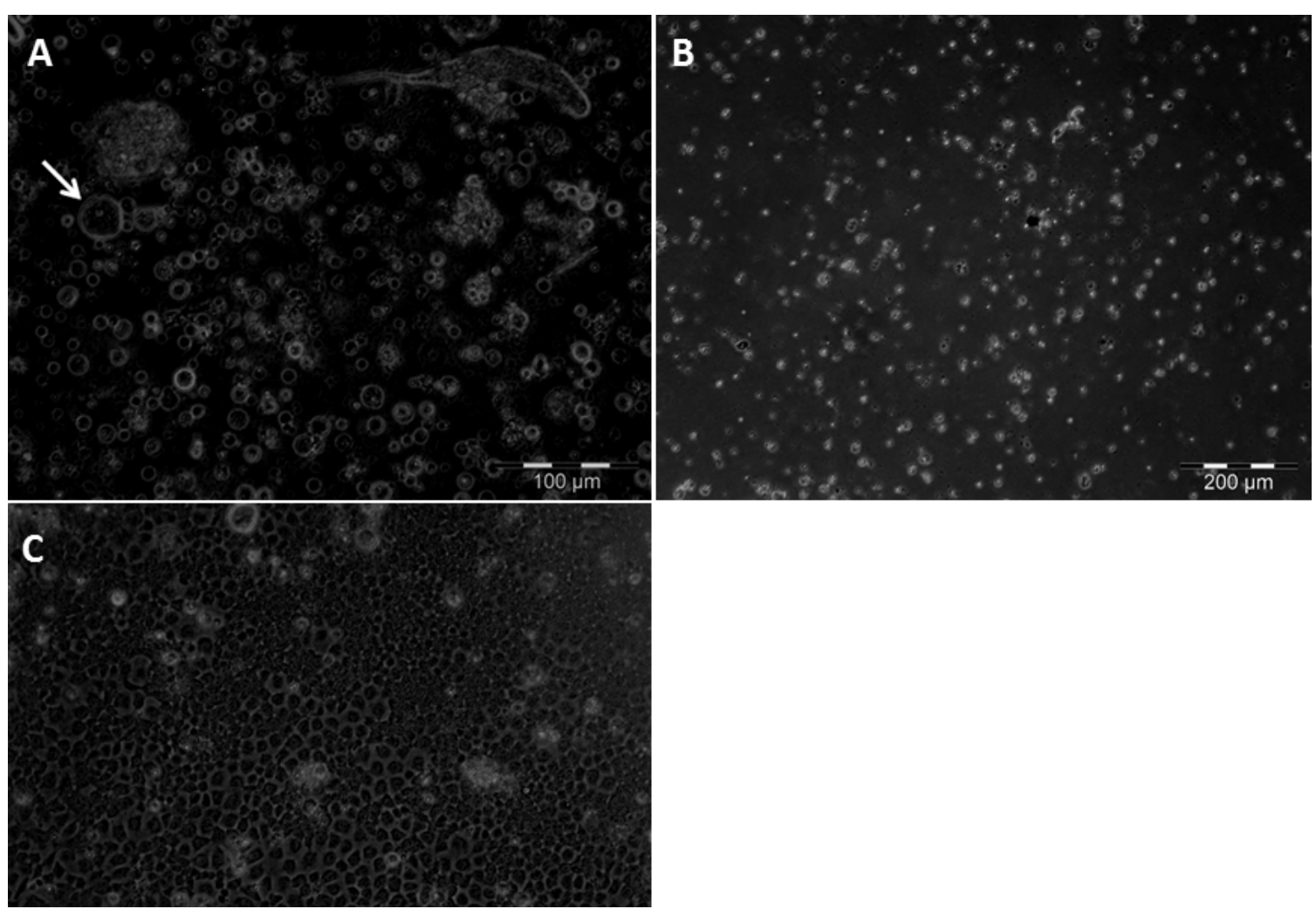

Figure 1. (A) Spherical cells belonging to 5th day of primary culture. While most of them were approximately $10 \mu \mathrm{m}$ in diameter, a few was bigger than $10 \mu \mathrm{m}$ in diameter. Arrow indicates the giant cell with a clear nucleus; (B) Suspension cells belonging to 14th day of primary culture. Most of these cells were between 10-15 $\mu \mathrm{m}$ in diameter; (C) Adherent cells tightly linked to those of neighboring in 20th day of primary culture. Size of these adherent cells was between 10-20 $\mu \mathrm{m}$ in diameter. 
Between $25^{\text {th }}$ and $60^{\text {th }}$ day of culture, number of adherent cells significantly increased according to $20^{\text {th }}$ day of culture and these cells covered nearly all bottom of petri dishes. Sizes of these cells were between $10-20 \mu \mathrm{m}$ in diameter. In $60^{\text {th }}$ day of culture, adherent cells were subcultured to new petri dishes with split ratio of 1:2.

\section{Subculture of Adherent and Suspension Cells}

In $7^{\text {th }}$ day of subculture made from adherent cells, there were adherent cell clumps found around the explant in different sizes. Some of them were remarkably in large size, which were approximately $100 \mu \mathrm{m}$ in diameter (Figure 2). These cells did not proliferate very well but they survive during 30 days after subcultured.

Contrary to adherent cells, first subculture for suspension cells was performed in $14^{\text {th }}$ day of primary culture. Doubling time of suspension cells was found to be 14 days and all passages (n: 5) for these cells were carried out in $14^{\text {th }}$ day of each subculture. Most of these cells were approximately $15 \mu \mathrm{m}$ in diameter and all of them were spherical cells.

\section{DISCUSSION}

Testes that are one of the reproductive tissues are used to investigate the development of spermatogenesis and to establish the primary or continuous cell lines in insect cell culture studies since cells obtained from this tissue are suitable to be cultured.

In first study related to culture of testes, it was reported that sperm follicles isolated from Samia cecropia were cultured in insect hemolymph and these cells survived for three weeks [14]. In a previous study, testes from diapausing pupae of Platysamia cecropia and Samia walkeri were cultured in hemolymph obtained from different stages of insects and effects of hemolymph on spermatogenesis were examined. Results of this study showed that some hormonal substances induce spermatogenesis [25]. In another study, spermatocytes from testes of Samia walkeri were cultured in presence of ecdysone for 1 hour and then they were transferred to medium containing high molecular weight substances found in hemolymph. Result of this study demonstrated that spermatocyte differentiated to sperm [26]. In 2007, testes obtained from Bombyx mori were cultured to enhance the production of apyrene sperm using a commercial medium, TC-100 cellculture medium, containing FBS at different rates and it was reported that when spermatocytes were cultured by TC-100 cell-culture medium containing $30 \%$ FBS, growth of eupyrene and apyrene bundles was found to be adequate [22].

These studies generally focus on development of spermatogenesis and do not aim to establish the primary cell culture or continuous cell lines.

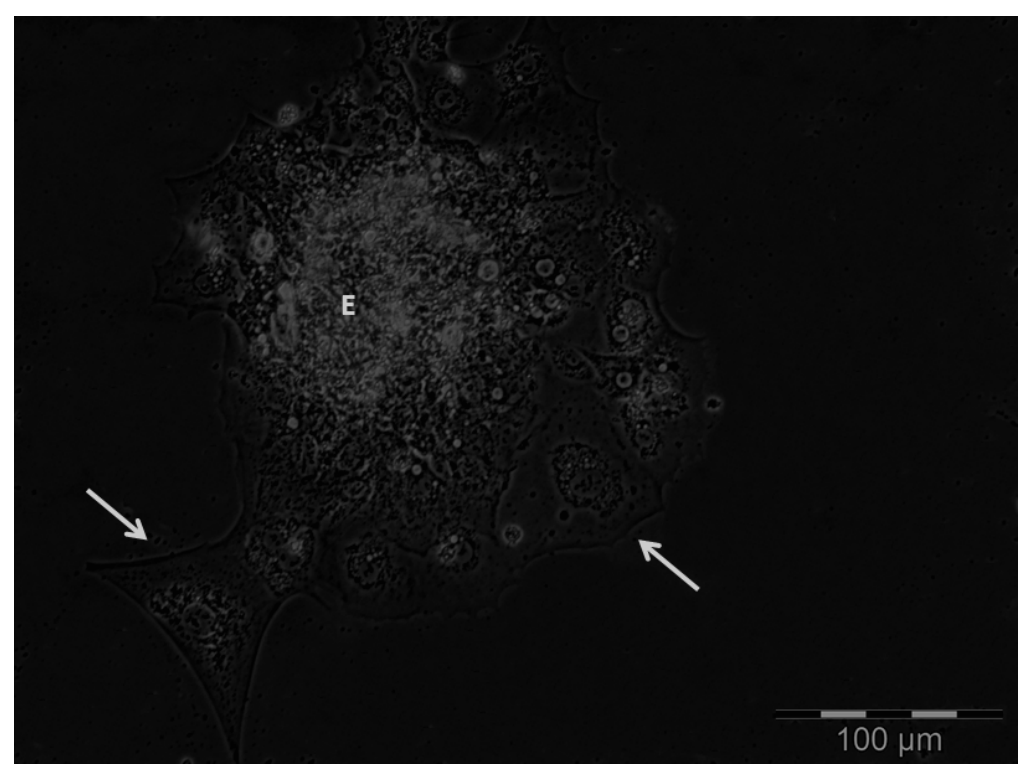

Figure 2. Huge adherent cells found around the explant (E) in subculture of adherent cells. Arrows indicate huge adherent cells. 
As differently from these studies, the first aim of our study is to establish primary cell culture from testes of $B$. mori using Grace's insect medium containing $10 \%$ FBS. According to results of primary culture, suspension cells were evidently observed in $5^{\text {th }}$ day and first time subcultured in $14^{\text {th }}$ day of culture (Figure 1B). Growth rate of these suspension cells was found to be very rapid. In $20^{\text {th }}$ day of culture, cells situated in bottom of petri dish in which they were called as adherent cells were seen and they were observed as tightly linked to those of neighboring (Figure $1 C)$. In $60^{\text {th }}$ day of culture, adherent cells were first time subcultured. Growth rate in adherent cells was remarkable but when it was compared with suspension cells, it was found that growth rate of adherent cells was slower than that of suspension cells.

The other aim of our study is to investigate the appropriate cells obtained from testes for establishing continuous cell lines. According to results of adherent cell's subculture, some adherent cell clumps were seen around the explants (Figure 2). However, it was found that adherent cells were not suitable for passaging since they did not proliferate very well and did not survive long time after they were subcultured. Contrary to adherent cells, doubling time for suspension cells in subculture was 14 days. Therefore, it was thought that suspension cells were convenient to establish continuous cell lines.

In a cell culture study established from testes of Chilo suppressalis, another Lepidopteran, it was reported that three different cell types were found; first type was small epithelial cells which were about $20 \mu \mathrm{m}$ in diameter, second type was large phagocyte-like cells which were about $100 \mu \mathrm{m}$ in diameter, third type was very large epithelial-like cells which were about $300 \mu \mathrm{m}$ in diameter [17].

Similarly, our study showed different type cells among adherent cell groups. Some of them were small cells which were between 10-20 $\mu \mathrm{m}$ in diameter and these cells were only seen in primary culture (Figure $1 C$ ). Others were large cells which were about $100 \mu \mathrm{m}$ in diameter and these cells were seen around the explant after subcultured
(Figure 2). These cells thought to be epitheliallike cells. Interestingly, it was not mentioned the presence of suspension cells in study conducted by Mitsuhashi. However, presence and growth rate of suspension cells were remarkable in our study. These two different results are thought to be depending on species of insects which were used in these studies because different species of insects were used in these studies.

Consequently, it was seen that primary cell culture from testes of $B$. mori resulted in suspension and adherent cell lines. In addition, this study showed that while adherent cells were not a good choice to initiate continuous cell lines, suspension cells were suitable to establish continuous cell lines. However, since suspension cell lines are generally used in production of recombinant proteins, further studies are required to show whether suspension cells produced in this study are appropriate in production of recombinant proteins or not.

\section{ACKNOWLEDGEMENTS}

The authors would like to thank to Bursa Kozabirlik Company, Bursa, Turkey for providing eggs of $B$. mori.

\section{References}

1. G. Smagghe, C.L. Goodman, D. Stanley, Insect cell culture and applications to research and pest management, In Vitro Cell Dev. Biol. Anim., 45 (2009) 93-105.

2. D. Gundersen-Rindal, E.M. Dougherty, Evidence for integration of Glyptapanteles indiensis polydnavirus DNA into the chromosome of Lymantria dispar in vitro, Virus Res., 66 (2000) 27-37.

3. U. Mudiganti, R. Hernandez, D. Ferreira, D.R. Brown, Sindbis virus infection of two model insect cell systems: A comparative study, Virus Res., 122 (2006) 28-34.

4. S. Schütz, P. Sarnow, Interaction of viruses with the mammalian RNA interference pathway, Virology., 344 (2006) 151-157.

5. E. Lennan, R. Vandergaast, P.D. Friesen, Baculovirus caspase inhibitors P49 and P35 block virus-induced apoptosis downstream of effector caspase DrICE activation in Drosophila melanogaster cells, J. Virol., 81 (2007) 9319-9330.

6. H. Li, B.C. Bonning, Evaluation of the insecticidal efficacy of wild type and recombinant baculoviruses, In: Murhammer DW, editor. Methods in molecular biology series, Baculovirus and insect cell expression protocols, 2007, pp 379-404. Springer, New York. 
7. D.E. Lynn, Lepidopteran insect cell line isolation from insect tissue, Methods Mol Biol., 388 (2007) 139-154.

8. M. Beckmann, K.J. Haack, Chemical pest controlinsecticides for agriculture, Chem. Unserer. Zeit., 37 (2003) 88-97.

9. B. Lemaitre, J. Hoffmann, The host defense of Drosophila melanogaster, Annu. Rev. Immunol., 25 (2007) 697-743.

10. K. Iwabuchi, A continuous cell line derived from larval fat bodies of Thysanoplusia intermixta (Lepidoptera: Noctuidae), Appl. Entomol. Zool., 35 (2000) 245-249.

11. M.M. van Oers, D.E. Lynn, Insect cell culture. Encyclopedia of Life Sciences, John Wiley Sons Ltd., Chichester., (2010) 1-5.

12. D.E. Lynn, Novel techniques to establish new insect cell lines, In Vitro Cell. Dev. Biol. Anim., 37 (2001) 319321.

13. S. Soya, H. Can, M.S. Yıkılmaz, Primary insect cell culture from total embryo and embryonic brain tissue of Periplaneta americana: A preliminary study, Archives of Biological Sciences, 67 (2015) 1203-1208.

14. R.Goldschmidt, Some experiments on spermatogenesis in vitro, Proc. NatI. Acad. Sci., USA, 1 (1915) 220-222.

15. C. Stern, The growth of testes in Drosophila. I. The relation between vas deferens and testis within various species, J. Exp. Zool., 87 (1941) 113- 158.

16. E.L. Schmidt, C.M. Williams, Physıology of insect diapause. Assay for growth and differentiation hormone of Lepidoptera by the method of tissue culture, Anat. Rec. Suppl., 105 (1953) 174-187.

17. J. Mitsuhashi, Tissue Culture of the Rice Stem Borer, Chilo suppressalis WALKER (Lepidoptera: Pyralidae) I. Cell Migration from the Explanted Tissues of Diapausing Larvae, Japanese Journal of Applied Entomology and Zoology, 9 (1965) 217-224.
18. M. Kambysellis, C. Williams, In vitro development of insect tissues. II. The role of ecdysone in the spermatogenesis of silkworms, Biol. Bull., 141 (1971) 541-552.

19. Y. Kuroda, Studies on Drosophila embryonic cells in vitro. I. Characteristics of cell types in culture, Develop. Growth. Differ., 16 (1974) 55-66.

20. S. Yagi, T. Fukushima, Hormonal effect on cultivated insect tissues. II. Effects of juvenile hormone on spermatogenesis of the silkworm, Bombyx mori L. in vitro (Lepidoptera: Bombycidae), Appl. Entomol. Zool., 10 (1975) 77-83.

21. N. Kawamura, K. Sahara, In vitro cultivation of spermatocysts to matured sperm in the silkworm Bombyx mori, Dev. Growth. Differ., 44 (2002) 273-280.

22. H. Hamada, H. Fugo, Effect of fetal bovine serum on the enhancement of in-vitro cultivation of spermatocysts of the silkworm, Bombyx mori L. (Lepidoptera: Bombycidae), Zoolog. Sci., 24 (2007) 1251-1258.

23. M. Njogu, P.G. Ricketts, A.V. Klaus, Spermatogenic cyst and organ culture in Drosophila pseudoobscura, Cell. Tissue. Res., 341 (2010) 453-464.

24. S.M. Gärtner, C. Rathke, R. Renkawitz-Pohl, S. Awe, Ex vivo culture of Drosophila pupal testis and single male germ-line cysts: dissection, imaging, and pharmacological treatment, J. Vis. Exp., 11 (2014) 51868.

25. C.M. Williams, M.P. Kambysellis, In vitro action of Ecdysone. Proc. Natl. Acad. Sci., 63 (1969) 231.

26. J. Mitsuhashi, Determination of Essential Amino Acids for Insect Cell Lines. In: Maramorosch K, Mitsuhashi J, editors. Invertebrate Cell Culture Applications., Academic Press, INC; 1982. p. 9-53. 